\title{
Insurance Provision for College Librarians
}

As a step in promoting interest in the welfare provisions available to college library staffs, Mrs. Hobbie presents certain facts gathered through an inquiry.

$\mathbf{S}^{\text {ome time ago the question was raised as }}$ $\mathrm{S}$ to what the colleges and universities are doing for their library staffs as far as certain phases of social security are concerned. Since no material was readily available on the subject, administrative officers of sixty-eight institutions were consulted in an attempt to find the facts. ${ }^{1}$

\section{Hospital Insurance}

The most popular form of social security in force in these institutions is hospital insurance. All but ten of the colleges approached reported some form of this insurance available. In the majority of the institutions it takes the form of the wellknown Blue Cross or Associated Hospital Service or some similar plan.

The terms of these services are more or less familiar. Enrolment is available through groups made up at the place of employment and is based on the number employed. If more than twenty-five are on the pay rolls, 40 per cent of the employees must enroll.

The types of service offered by the various plans are similar. The insurance provides: a semiprivate hospital room; twenty-one days' care the first year, twenty-

\footnotetext{
1 The colleges and universities concerned are listed at the end of this article.
}

four days the second, and so on; room and board at about $\$ 4.50$ per day ; use of operating room; general nursing care; ordinary drugs and medicines; surgical dressings; $x$-ray examinations up to thirty-five dollars; laboratory examinations up to twenty-five dollars; electro-cardiograms up to fifteen dollars; anesthetic service; physical therapy; metabolism tests; 25 per cent reduction on all above items for sixty additional days; insurance for family group as well as individual; maternity benefits, under family contracts. The plans do not include hospital care for mental disorders, drug addiction, alcoholism, or pulmonary tuberculosis. Hospital service is not provided for in accident cases which would be covered by employer's compensation or liability insurance. Private rooms in the hospital are allowed upon payment of additional fees.

This type of hospital insurance obviates red tape, assessments, age limitations, physical examinations, enrolment fees, and waiting periods. In the majority of the institutions insurance premiums are deducted either monthly or quarterly from employees' salaries and are paid to the insurance companies by the college treasurers. However, in six of the institutions the insured pay the premiums directly to the companies. The fees vary from ninety cents per month for an individual to thirty-five dollars per year for a family. In two instances the college pays one-quarter or onehalf of the premiums. In all other cases 
TABLB I

Hospital-Life Insurance Plan and Contribution by Various Employees

\begin{tabular}{|c|c|c|c|c|c|c|}
\hline \multirow[t]{2}{*}{ Classification } & \multirow{2}{*}{ 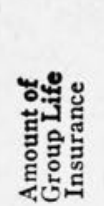 } & \multirow{2}{*}{ 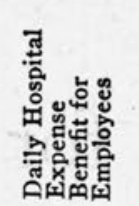 } & \multirow{2}{*}{ 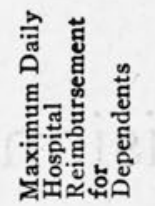 } & \multicolumn{2}{|c|}{$\begin{array}{l}\text { Maximum } \\
\text { Reimbursement } \\
\text { for } \\
\text { "Additional } \\
\text { Charges" }\end{array}$} & \multirow{2}{*}{$\begin{array}{c}\text { Employee's } \\
\text { Monthly } \\
\text { Contribution } \\
\text { Employee With De } \\
\text { only pendents }\end{array}$} \\
\hline & & & & $\begin{array}{c}\text { Employ- } \\
\text { ees }\end{array}$ & $\begin{array}{l}\text { Depend. } \\
\text { ents }\end{array}$ & \\
\hline
\end{tabular}

Professors, Assistant

Professors and Adminis-

trative Officers of

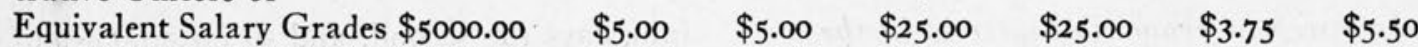

Instructors, Part-time

Instructors, Other

Administrative Officers,

Staff Assistants

$\$ 3000.00 \quad \$ 5.00$

$\$ 5.00$

$\$ 25.00 \quad \$ 25.00$

$\$ 2.55$

$\$ 4 \cdot 30$

All Other Employees

$\$ 2000.00 \quad \$ 3.00$

$\$ 3.00$

$\$ 15.00$

$\$ 15.00$

$\$ 1.65$

$\$ 2.45$

the premiums are paid in full by the insured.

The variations in coverage under these plans are interesting. One college sponsors an arrangement which gives a daily benefit of five dollars for a maximum of thirty-one days during each period of disability. The number of such periods of disability during any one year is not limited. Reimbursements are made for hospital fees up to twenty-five dollars.

A group of colleges in one state combines the Associated Hospital Services with physicians' services, offering a combination of hospital and medical insurance. This makes available the services of any of 5300 physicians and specialists in the state. The terms of these contracts include: service up to one year for each disease or injury; treatment at doctor's office; treatment at home if patient is unable to go to doctor's office; treatment at hospital when necessary; surgical operations; $x$-ray examination and diagnosis; $\mathrm{x}$-ray and radium treatments, in or out of the hospital ; laboratory tests, in or out of the hospital; services of a physician-anesthetist; consultations as required; premarital examination as re- quired by law; examination and treatment or refraction of eyes; operations for tonsils, adenoids, hernia, nasal septum (after one year); and obstetrical treatment (after two years). Excluded are services for mental disorders, drug addiction, alcoholism, and injuries covered by compensation laws. This physicians' service is available to those whose annual family net income is three thousand dollars or less, although hospital insurance is open to all, regardless of income. Full coverage (complete medical, surgical, and hospital service) costs two dollars per member per month.

In another institution group hospital insurance is combined with cooperative life insurance, and the amount of the insurance premium as well as the hospital allowance is dependent on the salary earned. Rates for this are shown in Table I. The librarian and the members of the library staff are included in the three groups.

In another college hospital insurance is provided (room, meals, etc., plus twentyfive dollars allowance for special fees) and surgical and medical reimbursements up to \$150. However, only the librarian, assistant librarian, and department heads are 
eligible to participate in the plan. General and clerical assistants are not included.

Although a number of colleges reported operating infirmaries for the benefit of their students, only two stated that such facilities are available for faculty and staff. The fee charged in the first case is two dollars per day. The other college offers its faculty and "other commissioned workers, of which the library staff are a part, a 20 per cent discount on all charges incurred at the college hospital, with no charge for doctors' services, other than surgery."

There is considerable variation in practice regarding hospital insurance for dependents. In some instances only the insured is eligible to participate in the group plan, while in other cases wives, children (up to eighteen years of age), and dependent parents may be included under the family plan.

Another interesting variation of the general plans in use is reported by two institutions. In both cases hospital insurance is combined with compulsory life insurance, the premiums varying according to the age of the insured.

\section{Life Insurance}

As far as straight life insurance is concerned, thirty-seven colleges reported that it is carried for their library staffs. In each case the college pays part of the premiums. The usual procedure is to combine the life insurance with retirement funds. Where this combination is offered to the faculty and library staffs, it is, in the majority of cases, compulsory.

The procedure is similar in a number of institutions. Instructors, and administrative officers of that grade, are insured for one or two thousand dollars, assistant professors for two or three thousand, and professors and higher ranking administrative officers for three or five thousand dollars.
Two colleges reported that the amounts of insurance carried were dependent on individual salaries received and varied from $\$ 1500$ to $\$ 6000$. In the majority of institutions providing life insurance for their faculties, members of the library staffs were included in the insurable group, although five colleges reported carrying life insurance for their professional library staffs but not for the clerical workers.

There is a great difference in the amounts contributed by the colleges toward the payment of premiums. These range from 5 per cent, the lowest, to 100 per cent, for one thousand dollar policies. Others stated that the institutions contributed "all cost in excess of the member's contributions," and these ranged from sixty cents per month to ninety-five cents per month, for the samesized policy. From one college came the statement that "matters of insurance are left entirely with the staff members as individuals."

\section{Health Insurance}

The number of colleges in the group concerned which are interested in health insurance for either faculty or library staff is limited to six, and as many different plans are in operation. The one thing in common among the six colleges is that no one of them pays the premiums for this insurance. In fact in only one instance is the premium even shared by the college.

The terms in the six cases vary greatly. Two reported benefits ranging from ten dollars to twenty-five dollars per week. A third reported reimbursements up to two hundred dollars for each sickness, while still another "pays $\$ 50$ per month beginning the eighth day of sickness." The premium charges ranged from a flat fee of fifteen dollars per year to a more elaborate scheme based on salary and combined with accident insurance. 
The fifth college in this group of six uses the following table for determining indemnity and monthly costs.

\section{TABLE II}

\section{Rates For Group Accident and Sickness} Insurance Plan

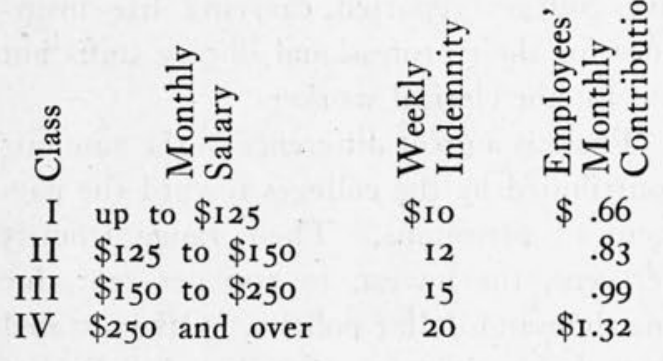

The last of the colleges in this group states that it reimburses the insured for any medical expenses, such as doctor, hospital, infirmary, nurse, x-ray, laboratory, etc., which may originate from sickness, whether at the college, at home, or while traveling. It does not cover "loss caused by war, or any act of war; nor does it cover the hazards of aviation (except while riding as a fare-paying passenger in a passenger aircraft carrier)." Moreover, "nonmedical expenses, such as cost of transportation, telephone, replacing eyeglasses, and dental treatment, unless necessitated by injury to sound and unfilled natural teeth, are not covered."

\section{Conclusions}

Do college librarians enjoy in any thorough sense the advantages of social security? The answer seems to be very definitely, no. There is no uniformity in what is available to library staff members, or even to faculty members, in the fields of hospital, health, and life insurance. So far as any or all of these are found, each institution is a law unto itself as to what is offered and how it is executed. No one type of institution does more for its members than another. Neither does size of institution nor region of the country in which it is located, enter into the picture. It is encouraging to note that, in the majority of cases, the institutions state definitely that any plans in operation are open to the library staffs as well as to the teaching faculty, although in a few instances professional staffs were included while clerical staffs were not provided for.

\section{Institutions Cooperating in Study}

Agnes Scott College, Albion College, Alfred University, Amherst College, Bennington College, Berea College, Birmingham-Southern College, Bowdoin College, Brigham Young University, Bryn Mawr College, Bucknell University, Carleton College, Associated Colleges in Claremont (Claremont, Pomona, and Scripps), Clark University, Coe College, Colgate University, Colorado College, Connecticut College, Dartmouth College, Davidson College, Denison University, DePauw University, Earlham College, Elmira College, Franklin College, Franklin and Marshall College, Georgia State College for Women, Goucher College, Hardin-Simmons University, Hobart College, Hood College, John B. Stetson University, Kalamazoo College, Knox College, Lawrence College, Mary HardinBaylor College, Massachusetts State College, Middlebury College, Mills College, Mount Holyoke College, New Jersey College for Women, Oberlin College, Oglethorpe University, Oklahoma Baptist University, Oklahoma College for Women, Radcliffe College, Randolph-Macon Woman's College, Reed College, Rollins College, Russell Sage College, Sarah Lawrence College, Skidmore College, Smith College, Southern Methodist University, Texas Christian University, Texas State College for Women, Texas Wesleyan College, Trinity College, Union College, Vassar College, Wellesley College, Wells College, Wheaton College, Whittier College, William and Mary College, Wittenberg College. 